\title{
The Problematic Jurisprudence on the Law of Defilement of Adolescents in Kenya
}

\author{
Henry Okwatch*
}

\begin{abstract}
The intention of the drafters of the 2006 Sexual Offences Act of Kenya was to curb the growing number of sexual crimes. The application of Section 8 of the Act by courts of law has, encountered some challenges, however, especially where adolescents are involved. Key among them is the identification of a victim where there is mutual defilement by children; the interpretation of Section 8(5) and (6) which provides a defence where the said child acted as an adult; the unjust outcomes of the mandatory minimum sentences in the Act; and the potential hindrance to the right to access reproductive health by adolescents. Therefore, this study seeks to provide solutions in dealing with these challenges. It advances the position that in certain instances, adolescents may consent to sexual intercourse, and so, stiff criminal sanctions may seem unwarranted. This study will rely on multidisciplinary studies such as medicine, in addition to the law, to further this argument. It proposes certain legislative reforms in order to avoid injustices while maintaining the legitimate interests of society to protect minors from sexual molestation.
\end{abstract}

Keywords: Sexual offences Act, adolescents, mutual defilement and criminal law

\section{Introduction}

In a bid to protect children from sexual molestation, Parliament passed the law on defilement under the Sexual Offences Act, 2006 (SOA) which has been in operation since the $21^{\text {st }}$ of July 2006. Its interpretation and application

* The author holds an LL.B (Hons) from Moi University, Kenya and is a student at the Kenya School of Law. The author would like to acknowledge the members of firm C6 at the Kenya School of Law for the insights into this paper. 
has, however, been met with various controversies. Chief among them is how to treat adolescents having consensual sexual intercourse. The law does not explicitly recognise adolescent consensual sex and prescribes punishment for all sexual intercourse involving persons under the age of eighteen. Further, in the case of consensual sex between adolescents, Kenyan case law demonstrates the misguided view that boys are the offending party, despite the language of the statute being gender neutral. ${ }^{1}$

The upshot of this is that various social and political issues have been raised concerning the proper way to grant autonomy to adolescents while still protecting them from sexual molestation. ${ }^{2}$ Should adolescents who have consensual sexual relations with their fellow adolescents be prosecuted jointly or separately? If only one party is to be prosecuted, what parameters should determine the most culpable party? Should the burden of proof pertaining mistake on the age of the accused shift to the accused person; or can the court take into consideration the behaviour of the victim in determining the case? Do the stiff mandatory minimum sentences in the SOA vitiate the accused person's right to a fair trial? And finally, does the criminalisation of consensual teenage sex potentially hinder the right of access to reproductive health?

The legal age of sexual consent varies widely across the globe from the age of eleven in Nigeria to twenty one in Bahrain. ${ }^{3}$ Under Kenyan law, defilement, also known as statutory rape in some jurisdictions, is defined as the act which causes penetration with a child. ${ }^{4} \mathrm{~A}$ child is defined as a person who is aged below eighteen years. ${ }^{5}$ The assumption at law is that a person aged below eighteen years is incapable of giving consent for purposes of sexual intercourse as they are incapable of appreciating the nature of the act. ${ }^{6}$ The import of the Kenyan SOA is that sexual intercourse with a person under the age of eighteen is a strict liability offence. $^{7}$ Punishment is on a graduated scale, based on the age of the victim. ${ }^{8}$ Persons who are found guilty of defilement of a child aged less than eleven years

1 See the cases of CKW v Attorney General \& Another (2014) eKLR; P O O (a minor) v Director of Public Prosecutions \& Another (2017) eKLR; and G.O. v Republic (2017) eKLR.

2 Phipps C, 'Misdirected reform: On regulating consensual sexual activity between teenagers' 12(3) Cornell Journal of Law and Public Policy, 2003, 374.

3 Petroni S, Das M and Sawyer S, 'Protection versus rights: Age of marriage versus age of sexual consent' The Lancet, 2018, 1 - < https://www.thelancet.com/journals/lanchi/article/PIIS23524642(18)30336-5/fulltext> on 14 December 2018.

4 Section 8, Sexual Offences Act (Act No. 3 of 2006).

Article 260, Constitution of Kenya (2010).

Section 43(1) (c), The Sexual Offences Act, (Act No. 3 of 2006).

See George Gathere Gichora v Republic, (2012) eKLR, 1-2.

See George Gathere Gichora v Republic, (2012) eKLR, 1-2. 
are sentenced to life imprisonment.. If the victim is between the age of twelve and fifteen years, the accused is sentenced to a term of not less than twenty years ${ }^{10}$ and if the victim is aged between sixteen and eighteen years of age, the accused is sentenced to a term of imprisonment of not less than fifteen years. ${ }^{11}$

Sexual feelings, however, are a natural part of growth and development of a person, and especially for adolescents. ${ }^{12}$ At that stage of their development, adolescents experience intense sexual urges that are sometimes difficult to ignore. ${ }^{13}$ The criminalisation of acts associated with the natural development of a human being seems inappropriate in that regard. Further, defilement occurs in different contexts, as in the context of two adolescents having consensual sexual intercourse, thus the provision for mandatory stiff punishments for all sexual relations with adolescents would perhaps be inappropriate.

It is from this perspective that the study intends to analyse the offence of defilement as provided in Section 8 of the SOA. Part I has provided a brief introduction, exposing the reader to the problem that the study intends to tackle. In Part II, the study will attempt to theorise the law on defilement, and the need to treat defilement of adolescents differently. It will further provide contrasting views regarding the issue of defilement on adolescents and attempt to show why stiff and mandatory sentences are inappropriate. In Part III, the study will provide the criticisms surrounding the enforcement of the law on defilement on adolescents. The arguments in the study will be enriched by a comparative study in Part IV. The study will then provide proposals for legislative reform in Part V followed by the conclusion in Part VI.

\section{Theorising Defilement Law}

\section{i. Feminist Legal Thought}

Gordon defines feminism as the 'analysis of women's subordination for figuring out how to change it. ${ }^{14}$ Bowman and Schneider divide feminist legal

\footnotetext{
Section 8(2), Sexual Offences Act, (Act No. 3 of 2006).

Section 8(3), Sexual Offences Act, (Act No. 3 of 2006).

Section 8(4), Sexual Offences Act, (Act No. 3 of 2006).

2 World Health Organization, 'Defining sexual health: Report of a technical consultation on Sexual Health', 2006, 5.

13 Papathanasiou I, 'Adolescence, sexuality and sexual education' 1 Health Science Journal, (2014), 4.

14 Gordon L, 'The struggle for reproductive freedom: Three stages of feminism', in Eisenstein Z (ed.) Capitalist patriarchy and the case for socialist feminism, Monthly Review Press, 1979, 107.
} 
theory into four major schools of thought; formal equality theory, 'cultural feminism' theory, dominance theory and post-modern theory. ${ }^{15}$ Formal equality theorists argue that women should be treated the same way as men. ${ }^{16}$ The cultural feminist theory, on the other hand, is rooted in the idea that men and women are different and those differences should be encouraged and celebrated. ${ }^{17}$ The dominance theorists seek to challenge the embedded structures of power that make the characteristics of men the norm from which difference is construed. ${ }^{18}$ The post-modern theory, on the other hand, takes the view that there is no single female voice. The female voice is affected by an intersection of various aspects such as race, gender and class therefore feminism should be construed in light of the intersection of those voices. ${ }^{19}$

Feminist legal thought, however, provides divergent thoughts on the issue of defilement, particularly between feminists who support formal equality and those that support substantive equality (dominance theorists). ${ }^{20}$ Olsen notes the paradox of statutory rape laws that on one hand protect females, while on the other hand, they restrict sexual activity of young women and reinforce a double standard of sexual morality. ${ }^{21}$ The result is the tension as to whether the state should intervene to protect young girls by use of laws against defilement, or relax the laws to allow positive views of teenage sexuality.

Kitrosser, who supports formal equality between men and women, asserts that the two sexes should be treated the same; and fears that legal thinkers will confuse biological differences with socially constructed differences and use them to justify discriminatory treatment. ${ }^{22}$ She opposes the social construct that it is the men who will always seek sexual favours from women and therefore the women must be protected from sexual access by sexually aggressive men. ${ }^{23}$ The result is that excessively strict statutory rape laws unduly restrict the sexual freedom

15 Bowman C and Schneider E, 'Feminist legal theory, feminist lawmaking and the legal profession' 67(2) Fordham Law Review, 199, 251.

16 Bowman $C$ and Schneider E, 'Feminist legal theory, feminist lawmaking and the legal profession' 251.

17 Cain P, 'Feminist jurisprudence: Grounding the theories' 4(2) Berkeley Journal of Gender, Law and Justice, 1989, 200.

18 Bowman $\mathrm{C}$ and Schneider E, 'Feminist legal theory, feminist lawmaking and the legal profession,' 251.

19 Bowman C and Schneider E, 'Feminist legal theory, feminist lawmaking and the legal profession,' 251.

20 See Barth K, 'Defining 'sexual abuse of a minor' in Immigration Law: Finding a place for uniformity, fairness, and feminism, 881.

21 See Christopher R. and Christopher K, 'The paradox of statutory rape' 87 Indiana Law Journal, (2012), 516.

22 Burgess-Jackson K, 'Statutory rape: A philosophical analysis', 145.

23 Barth K, 'Defining 'sexual abuse of a minor' in immigration law: Finding a place for uniformity, fairness, and feminism’ 8(2) Seattle Journal for Social Justice, 2010, 881. 
of young women who should equally be allowed to explore their sexuality. ${ }^{24}$ The support for decriminalisation of statutory rape reflects the expectation that sometimes girls should be sexually accessible to males. ${ }^{25}$

McClain advocates for the liberal approach of emphasising sexual and reproductive responsibility on the basis of capacity and equality. ${ }^{26}$ She advocates for healthy expressions of sexual desire by adolescents as a way to develop the adolescent's sexual self. ${ }^{27}$ Young women are therefore seen as persons who are capable of effective self-governance in the realm of sexual relations. Her ideas are supported by Smart, who takes the view that attempts to reform statutory rape laws may in effect repress 'good sex'. ${ }^{28}$ Further, she asserts that the enforcement of those laws also runs the risk of being turned into a traditional moral purity campaign. ${ }^{29}$

Formal equality as a theory has been criticised for not recognising the structural imbalance of power that exists between men and women, therefore giving an illusion of equality while, in effect, entrenching the same inequalities. ${ }^{30}$ Feminists who advocate for substantive equality such as Mackinon recognise the deep and entrenched inequalities that are present in the interactions of the two sexes. They make the argument that women often acquiesce to sex for various reasons which should negate consent especially for young women. ${ }^{31}$ For example, a young woman who consensually has sex with an adult for financial upkeep, for certain favours, or to fit into a certain community's harmful cultural practices such as forced marriage. ${ }^{32}$ Substantive equality feminists thus advocate for highly restrictive statutory rape laws, with the assumption that it serves to protect younger women from sexual exploitation by men. ${ }^{33}$

24 Barth K, 'Defining 'sexual abuse of a minor' in immigration law: Finding a place for uniformity, fairness, and feminism', 881.

25 Roberts D, 'The meaning of gender equality in criminal law' 85(1) Journal of Criminal Law and Criminology, (1994), 6.

26 Mcclain L, 'Some ABCs of feminist sex education (in light of the sexuality critique of legal feminism)' 15(1) Columbia Journal of Gender and Law, 2006, 67.

27 Mcclain L, 'Some ABCs of feminist sex education (in light of the sexuality critique of legal feminism)', 67.

28 Henderson L, 'Law's patriarchy' 25(2) Law and Society Review, 1991, 433.

29 Henderson L, 'Law's patriarchy' 25(2) Law and Society Review, 1991, 433.

30 Fiss M, 'Groups and equal protection clause' Philosophy and Public Affairs, 1976, 107.

31 Barth K, 'Defining 'sexual abuse of a minor' in immigration law: finding a place for uniformity, fairness, and feminism', 882.

32 West R, 'Sex, Law and Consent' In Wertheimer A \& Miller A (eds.) The ethics of consent: Theory and practice, Oxford University Press, 2009, 6.

33 Kitrosser H, 'Meaningful consent: Towards a new generation of statutory rape laws' 4 Virginia Journal of Social Policy \& Law, 1997, 311. 
In Mackinon's view, male dominance is sexual. ${ }^{34}$ Social ills such as defilement are part of the expression of male dominance over women. ${ }^{35}$ While discounting the Freudian conception that children too are born sexual, ${ }^{36}$ she states that infants, although sensory, cannot be said to be sexual in that they have not had the experiences that give social meaning to sexual intercourse. ${ }^{37}$ In effect, children should be considered asexual and incapable of any sexual consent. Halley also takes that standpoint with the view that there still exists pervasive inequality between young men and young women. She points out that as boys enter adulthood, they enter a realm of safety and state created equality. A girl, on the other hand, as she grows into adulthood, enters a realm of vulnerability and inequality. ${ }^{38}$ Young women must therefore be protected from these sexual inequalities.

These contrasting feminist views can find a meeting point in defilement laws that do not unnecessarily restrict female sexual autonomy, but at the same time protect young women from sexual exploitation. The Committee on the Convention on the Rights of the Child reminds state parties to protect children up to the age of eighteen from exploitation of all kinds, and to balance the protection with the evolving capacities in determining the age of consent. ${ }^{39}$ The Committee further asks state parties to avoid criminalising factually consensual sex between adolescents. ${ }^{40}$ As Kangaude notes, the capacity of the child is not static. ${ }^{41}$ The age of consent must not be set too high, where it will undermine adolescent autonomy or too low to expose children to unwarranted harm and risk. ${ }^{42}$

\section{ii. A Children's Rights Approach}

Children seem to be an aberration in the human rights arena. On one hand, they have rights as autonomous human beings, ${ }^{43}$ and on the other hand,

Mackinon C, 'Sexuality, pornography and method' 99 (2) Ethics, 1989, 315.

Mackinon C, 'Sexuality, pornography and method', 315.

Mackinon C, 'Sexuality, pornography and method', 315.

Mackinon C, 'Sexuality, pornography and method', 341.

3 Mcclain L, 'Some ABCs of feminist sex education (in light of the sexuality critique of legal feminism)', 81.

39 CRC General Comment No. 20 (2016), The Implementation of the Rights of the Child during Adolescence, 6 December 2016, para. 40.

40 CRC General Comment No. 20 (2016), The Implementation of the Rights of the Child during Adolescence, 6 December 2016, para. 40.

${ }_{41}$ Kangaude G, 'Adolescent sex and 'defilement' in Malawi' 17 African Human Rights Law Journal, 2017, 545.

42 Kangaude G, 'Adolescent sex and 'defilement' in Malawi', 545

43 Ezer T, 'A positive right to protection for children' 7(1) Yale Human Rights and Development Journal, 2014, 1 . 
they are thought to be dependent on adults. ${ }^{44}$ The Constitution of Kenya, 2010 $(\mathrm{CoK})$ provides a hybrid of the two contrasting views. To begin with, the CoK recognises children as a vulnerable group of persons. ${ }^{45}$ This position is further buttressed by the special protection of children's rights under Article 53 which are unique from the other entitlements enjoyed by every person. ${ }^{46}$ However, the language of the other bundle of rights denotes 'every person', including children, have the right to those rights. ${ }^{47}$ In effect, there should be caution in the granting of autonomy to children. Where parents exercise autonomy on behalf of their children, they should do so for the child's best interest. ${ }^{48}$

On the first conception, that children are incapable of being autonomous rights holders, Locke regarded children as an exception to his general proposition that 'all men by nature are equal'. ${ }^{49}$ According to him, rights could only flow from a person capable of rational reason, from which children are excluded..$^{50}$ Parents, therefore, were justified to subjugate their children as they were completely dependent on them. ${ }^{51}$ Stuart also lends credence to this claim with the assertion that 'those who are still in a state to require being taken care of by others, must be protected against their own actions as well as against external injury, ${ }^{52}$ This conception of children's rights advocates for the restriction of the rights and entitlements of children by parents and, by extension, the state by the enforcement of statutory rape provisions. ${ }^{53}$ The result is that the state intervenes to protect children from sexual abuse by use of criminal law.

The African Charter on the Rights and Welfare of the Child (the Charter) is especially modelled on this conception. Article 1 of the Charter defines a child as a person below the age of eighteen years. ${ }^{54}$ It does not give any qualification as to the child's personal law as is provided for in the Convention on the Rights of the Child. ${ }^{55}$ Article 16 of the Charter is precise that every child should be protected

\footnotetext{
Ezer T, 'A positive right to protection for children', 1.

See Article 21(3), Constitution of Kenya (2010).

See Article 53, Constitution of Kenya, (2010).

See, for instance, Article 28, The Constitution of Kenya (2010).

4 Mkandawire L, 'The balance between child autonomy and parental autonomy in Malawi; an analysis of the child care, protection and justice act', unpublished LLM thesis, University of Cape Town, Cape Town, 2017, 17.

49 Locke J, Trwo Treatises of Government, Cambridge University Press, Cambridge, 1988, 304.

50 Locke J, Two Treatises of Government, 304.

51 Ezer T, 'A positive right to protection for children', 1.

52 Mill J, On Liberty, Legal Classics Library, Indianapolis, 1992, 22-23.

53 Ezer T, 'A positive right to protection for children', 1.

54 See Article 1, The African Charter on the Rights and Welfare of the Child, July 1990.

55 See Article 1, The Convention on the Rights of the Child, 20 November 1989, UNTCS 27531.
} 
from maltreatment including sexual abuse. ${ }^{56}$ In addition, Article 21 provides that governments should do what they can to prevent harmful social and cultural practices such as child marriages that affect the welfare and dignity of children. ${ }^{57}$ Article 27 of the Charter also asks state parties to take measures to protect the child from all forms of sexual exploitation and sexual abuse; and particularly to take measures to prevent the inducement, coercion or encouragement of a child to engage in any sexual activity, prostitution and the use of children in pornographic activities and performances. ${ }^{58}$ There is no room for the allowance of a child to consent to any sexual activity in the Charter.

Child liberationists, however, argue for the second conception and hold the view that children have absolute autonomy to enjoy their rights. ${ }^{59}$ Holt advocates that children should be able to enjoy full rights, duties and responsibilities as adults would. ${ }^{60}$ Farson makes the case that children should be allowed to any act that is acceptable by adult standards. ${ }^{61}$ At the heart of his argument is the right to self-determination which he posits should be available to children too. ${ }^{62}$ Cohen notes the concerns of the liberationists from the arguments in the United Nations General Assembly when the Convention on the Rights of the Child was first introduced (UNCRC). They argued that children did not need a separate treaty to protect their rights because the existing international human rights treaties already protected their rights. ${ }^{63}$ She notes that although the Convention on the Rights of the Child restates what is already in other human rights treaties, it makes those rights appropriate for the children. ${ }^{64}$ This is in line with the evolving international child rights norms that a child is not to be a 'pre-human' being but rather that childhood is part of the continuity of human development. ${ }^{65}$

\footnotetext{
56 See Article 16, The African Charter on the Rights and Welfare of the Child. See Article 16, The African Charter on the Rights and Welfare of the Child. See Article 27, The African Charter on the Rights and Welfare of the Child.

9 Mkandawire L, 'The balance between child autonomy and parental autonomy in Malawi; an analysis of the Child care, protection and justice act', 14.

60 See Geiser R, 'The rights of children' 28(4) Hastings Law Journal, (1977), 1044.

${ }^{61}$ See Geiser R, 'The rights of children', 1045.

62 See Geiser R, 'The rights of children', 1045.

63 Cohen C, 'The United Nations Convention of the Rights of the Child: A feminist landmark' 3(1) William and Mary Journal of Women and Law, (1997), 35.

64 Cohen C, 'The United Nations Convention of the Rights of the Child: A feminist landmark', 35.

${ }_{65}$ Mbambi R, 'Crisis of the girl child's rights: Victims of defilement and the Zambian courts', unpublished LLM thesis, University of Zambia, Lusaka, 2017, 7.
} 
The argument of the child being capable of being an autonomous rights holder was the crux of the decision in the case of Teddy Bear Clinic for Abused Children and Anotherv Minister of Justice and Constitutional Development and Another. ${ }^{66}$ In this case, the Constitutional Court of South Africa found that the criminalisation of consensual sexual intercourse by adolescents was inconsistent with South African children's right to dignity. ${ }^{67}$ The court stated that if one's consensual sexual choices are not respected by society, the innate self-worth of that person would be diminished. Further, the criminalisation of such has an impact on the social lives and dignity of that person. ${ }^{68}$ In addition, the court took the view that the criminalisation of such consensual sexual intercourse allowed police officers, prosecutors and judicial officers to scrutinise and assume control of the most intimate realm of their lives which is against the right to privacy ${ }^{69}$

The UNCRC also seems to match with the view that children, as they evolve, start to gain capacity to make certain autonomous decisions. Article 5 of the UNCRC tasks state parties to take into account the rights, duties and responsibilities of children in accordance with their evolving capacities ${ }^{70}$ In the author's view, adolescents, especially those in the late stage of development, have the prerequisite capacity to engage in certain acts of sexual intercourse in certain instances, owing to their stage of development. Article 12 of the UNCRC states that state parties should accord children who are capable of forming their own opinions the right to express those views freely in all matters affecting the child; with the views of the child being given due weight in accordance with the age and maturity of the child. ${ }^{71}$ This could provide a framework on which children can make certain decisions, in this case regarding their sexuality, without the consent of their parents, and the state should not interfere with these decisions by using criminal law. $^{72}$

${ }_{66}$ Teddy bear clinic for abused children and another $v$ Minister of justice and constitutional development and another, (2013) Constitutional Court of South Africa.

67 Teddy bear clinic for abused children and another $v$ Minister of justice and constitutional development and another, (2013) Constitutional Court of South Africa, para. 55.

68 Teddy bear clinic for abused children and another $v$ Minister of justice and constitutional development and another, (2013) Constitutional Court of South Africa, para. 55.

69 Teddy bear clinic for abused children and another $v$ Minister of justice and constitutional development and another, (2013) Constitutional Court of South Africa, para. 60.

70 Article 5, Convention on the Rights of the Child.

71 Article 12, Convention on the Rights of the Child.

72 Minow M, 'Interpreting rights: An essay for Robert Cover' 96(8) Yale Law Journal, 1987, 1882. 


\section{Criticisms in the Enforcement of the Law on Defilement in Kenya}

\section{i. Mutual Defilement by Children}

The enforcement of the SOA has been marred with certain controversies since its enactment in 2006. For instance, where a child has consensual sexual intercourse with another child, the situation becomes delicate as who is to be considered the victim and who is to be considered the perpetrator. The other dilemma is whether the adolescent, on being found guilty, should be subjected to a mandatory prison term as prescribed by the $\mathrm{SOA} .{ }^{73}$

In the case of $C K W v$ Attorney General $\&$ Another, the petitioner challenged the constitutionality of Sections 8(1) and 8(2) of the SOA on grounds that it discriminated against him. He had been charged, convicted and sentenced under the impugned sections for having sexual intercourse with a girl, who was the same age as he was; sixteen years. The petitioner complained that the said section discriminated against him as he was the only person who was charged with the offence and the girl was not charged. He claimed that the victim was his girlfriend and had consented to the act. ${ }^{74}$

The High Court declined to declare Section 8 of the SOA discriminatory. The Court stated that the law on defilement was appropriate because it sought to protect adolescents who, if left to their own devices, were likely to engage in risky behaviour. ${ }^{75}$ Further, the Court stated that the language of the statute itself did not distinguish between male and female and therefore, the said statute could not be declared unconstitutional on the basis that it was discriminatory on the basis of gender. ${ }^{76}$ The Court also found that the petitioner had not led any evidence to show the discriminatory reasons why he had been targeted and not the girlfriend. ${ }^{77}$

This decision could be criticised in light of Article 27 of the CoK. This Article protects Kenyan citizens from discrimination and declares that all persons are equal and should have the equal benefit of the law regardless of gender. ${ }^{78}$ The Constitution enjoins all state organs to observe, respect, protect, promote,

\footnotetext{
See Section 8, The Sexual Offences Act, (Act No 3 of 2006).

CKW v Attorney General E Another (2014) eKLR.

CKW v Attorney General \& Another (2014) eKLR, para. 81.

$C K W$ v Attorney General \& Another, para. 88.

$C K W$ v Attorney General \& Another, para. 91.

Article 27, Constitution of Kenya (2010).
} 
fulfill, and fully uphold the fundamental freedoms in the Bill of Rights. ${ }^{79}$ The argument by the court therefore seems superfluous since the government must not be moved to treat all offenders equally. If the implementation of a law, on the face of it, shows that the Petitioner has been discriminated against, the court should move forthwith to correct the breach of law.

The High Court of Kenya dealt with another constitutional challenge to prosecution of a defilement charge in the case of POO (a minor) v Director of Public Prosecutions $\&$ Another. ${ }^{80}$ In this case, the petitioner sued the office of the Director of Public Prosecutions alleging that the state organs had directly discriminated against him by charging him with defilement and not charging the girl he had had sexual intercourse with of the same charge as they were both minors. He argued that Section 3 of the Office of the Director of Public Prosecutions Act enjoined the Director of Public Prosecutions to act with impartiality and to observe gender equality. ${ }^{81}$ The court sided with him and held that the office of the Director of Public Prosecutions had discriminated against him on grounds of gender. The court went ahead to state that instead of prosecuting the accused, the two children should have been seen as victims of the offence rather than perpetrators.

The case of $G O v$ Republic had a peculiar set of facts. ${ }^{82}$ In this case, the Appellant was charged with the offence of defilement. He was fifteen years old however, and the girl concerned was seventeen years old at the time of commission of the offence. It was only the accused who was charged and convicted of the offence. He alleged that he had been discriminated against as it was only he who was arrested, and his partner was not. The court held that blame should not have been wholly shifted to the Appellant but should have been apportioned against both the Complainant and the Appellant. Since both were minors, they needed protection against harmful sexual activities and neither should be sent to prison. Thus, the sentence meted out on the accused was set aside, and he was placed on probation.

From the cases discussed above, there seems to be consensus among a number of judges that children who have sexual intercourse with other children are not necessarily criminals. They are rather victims of the offence and should not be given custodial sentences. It brings to the fore, however, the propriety

Article 21, Constitution of Kenya (2010).

(2017) eKLR.

See Section 3, Office of the Director of Public Prosecutions Act, (Act No. 2 of 2013).

(2017) eKLR. 
of the use of criminal law to prevent adolescents from engaging in consensual sexual intercourse among themselves. These adolescents are not really sexual predators but people exploring their sexuality. The Zimbabwean High Court noted in the case of State $v$ Brian Masuku that there was a difference between adult perpetrators of sexual offences and consensual relationships between adolescents. ${ }^{83}$ Tsanga $\mathrm{J}$ opined that if the State continued in its formalistic approach, ignoring the reality of teenage sex, it could not only result in unnecessary punitive sentences, but a criminal record and stigmatisation of the offender. If the mandatory prison sentence for the offence must remain, then the law should provide for a clear difference between situations where there is manipulation, and adolescent exploration on the other hand. ${ }^{84}$

In order to avoid claims for discrimination, both adolescents must be held accountable for the act of defilement. It is clear that young adolescent boys invariably bear the brunt of prosecution in cases where both victims are children. There is no legal bar for the prosecution to bring charges against both children in the case of mutual defilement by adolescents. This is unless there is evidence that there was some form of coercion or deceit against the complainant. ${ }^{85} \mathrm{It}$ might end in absurd results, however, having to arrest and prosecute pairs of adolescents for having consensual sexual intercourse.

\section{ii. The Judicial Treatment of Sections 8(5) and (6) of the Sexual Offences Act where the Victim Behaves Like an Adult}

Sections 8(5) and (6) of the SOA state that it shall be a defence to a charge of defilement if it is proved that; (a) the child deceived the accused that they were over the age of eighteen ${ }^{86}$ and; (b) the accused reasonably believed that the child was over the age of eighteen years. ${ }^{87}$ Further, sub-section 6 states that the reasonable belief that the accused was above the age of eighteen shall be construed, having regard to all circumstances including any steps taken by the accused to ascertain the age of the complainant.

\footnotetext{
State v Brian Masuku, (2015), Zimbabwe High Court, 2.

${ }^{84}$ Feltoe G, 'Strengthening our law on child sexual abuse' The Zimbabre Electronic Law Journal, 2017, 5 -<https://zimlii.org/system/files/journals/Strengthening\%20Our\%20Law\%20on \%20 Child\%20Sexual $\% 20$ Abuse.pdf $>$ on 14 December, 2018.

$85 C K W$ v Attorney General E another, paras. 60 and 61.

86 See Section 8(5) (a), Sexual Offences Act, (Act No. 3 of 2006).

87 See Section 8(5) (b), Sexual Offences Act, (Act No. 3 of 2006).
} 
These sub-sections have had varied interpretations. On one hand, courts have interpreted them that if the victim was a willing participant in the act, then they will be deemed to have been acting as an adult and therefore the accused will be entitled to benefit under Section 8(5) and (6) of the Act. ${ }^{88}$ On the other hand is the interpretation that if the accused intends to raise such a defence, the burden of proof shifts to them to prove that the child deceived them and that they reasonably believed that the child was over the age of eighteen. ${ }^{89}$

The most notable and controversial of the judicial interpretations is the case of Martin Charo $v$ Republic. ${ }^{90}$ The accused in this case had been convicted of the offence of defilement. The alleged victim was a girl aged fourteen years while the accused was twenty-four years old at the time. Evidence was adduced at the trial that the girl had sneaked out of her brother's house to go to the accused's house to have sexual intercourse. The court, while conceding that a child indeed cannot give consent for sexual intercourse, held, however, that the behaviour of the complainant before, during and after the sexual intercourse with the accused showed that she was mature and behaved like an adult. The judge considered circumstances such as: (i) Whether the complainant reported the defilement immediately after the incident (ii) Whether she was threatened after the incident (iii) How long it took her to report (iv) Whether there was a threat to her life (v) How long the relationship was and (vi) Whether the parents were aware of the relationship. The appeal was thus allowed and the accused set free.

The judgement sparked some controversy. Franceschi argues that the decision of the learned judge inexplicably shifted the onus of proof from the appellant, Mr Charo, to the victim in that case. ${ }^{91}$ Karige and Oswago also find credence in that argument on grounds that when dealing with children in a sexual circumstance, the onus should be on the adult to prove his innocence. ${ }^{92}$

88 See the cases of Martin Charo v Republic (2016) eKLR; Omus Kiringi Chivatsi v Republic (2017) eKLR; and Jane Mumbi Gichubi v Republic (2018) eKLR.

89 See the cases of Irene Atieno Ochieng v Republic (2017) eKLR and Luka Waithaka Ndegwa v Republic (2017) eKLR.

90 (2016) eKLR.

91 Franceschi L, 'Advice to young men in Charo's shoes' Daily Nation, 20 May $2016 \quad<$ https:// www.nation.co.ke/oped/blogs/dot9/franceschi/2274464-3211484-9deoid/index.html> on 10 November 2018.

92 Karige W and Oswago S, 'Can the sexual assault of children be compartmentalised: An introspective analysis of the ruling in Martin Charo v R No. 32 of 2015', Haki Blog, Kituo cha sheria, 10 May 2016 - <https://kituochasheria.wordpress.com/2016/05/10/can-the-sexual-assault-of-childrenbe-compartmentalized-an-introspective-analysis-of-the-ruling-in-martin-charo-r-no-32-of-2015/ > on 10 November 2018. 
Franceschi goes further to argue that for a child, enjoyment of sex does not denote consent and therefore is irrelevant and cannot sustain an acquittal. ${ }^{93}$

The position taken by Franceschi, Karige and Oswago also finds judicial support. Justice Mrima in the case of Irene Atieno Ochieng $v$ Republic ${ }^{94}$ was of the opinion that when the accused raises the defence under Sections 8(5) and (6), the onus of proof shifts to them to prove that the victim deceived them, and that they reasonably believed the victim to have been an adult. The defence given is then to be considered in light of all relevant circumstances, including steps taken by the accused to ascertain the age of the accused. Another close interpretation was in the case of Luka Waithaka Ndegwa v Republic ${ }^{55}$ where the Court, while explicitly disagreeing with the Martin Charo case, stated that it was neither the consent nor the behaviour of the victim that mattered, but rather the reasonable belief that the child is above the age of eighteen and evidence of the steps taken by the accused to ascertain the age of the accused. ${ }^{96}$

That interpretation is, however, not unanimous. Mativo J in the case of Duncun Mwai Gichubi v Republic ${ }^{97}$ maintained that the legal burden of proof never leaves the prosecution's backyard. ${ }^{98}$ In his view, the accused needed only to raise a reasonable defence to cast doubt on the prosecution's case. Further, he stated that the offence of defilement does not impute strict liability, and the prosecution must prove the culpable mind of the accused in order to prove his guilt. The accused should remain innocent throughout the trial until they are proven guilty. Similarly in the case of John Bundi Kinyua v Republic ${ }^{99}$ the court stated that the burden of proof does not shift to the accused in all criminal cases.

The above mentioned cases show the tensions in the interpretation of the defence that the accused was of the belief that the child was above the age of eighteen years. This author favours the approach that each defilement case be treated according to its peculiar circumstances. The burden of proof need not shift to the accused to prove the steps taken to ascertain the age of the accused, but rather the accused person need only raise a reasonable defence that he did not know that the victim was a minor. Certainly, the conduct of the child is relevant in this regard. For instance, the court in the case of Jane Gichubi

Franceschi L, 'Advice to young men in Charo's shoes'.

Atieno Ochieng v Republic (2017) eKLR.

Luka Waithaka Ndegwa v Republic (2017) eKLR.

Luka Waithaka Ndegwa v Republic, (2017) eKLR para. 20.

Duncun Mwai Gichubi v Republic (2015) eKLR.

Duncun Mrai Gichubi v Republic, (2015) eKLR, 9.

(2017) eKLR. 
Mumbi v Republic considered that if the complainant could change his school uniform to civilian, go to the bar and spend the night away, such behaviour did not indicate a minor who was innocent. ${ }^{100}$ This will do better to separate cases where adults manipulate adolescents into sexual intercourse from those in which the accused engaged in consensual sex with the adolescent. It prevents unjust rulings against adults who have consensual sexual intercourse with adolescents. Where the circumstances show that the adolescent was neither manipulated nor coerced into having sexual intercourse with the accused, therefore excluding the culpable mind, the court should be at liberty to set the accused free. ${ }^{101}$

\section{iii. Emphasis on Retribution and the Problem with Mandatory Minimum Sentences}

The justification of punishment is divided into two broad categories: the retributivist theories and the utilitarian theories. ${ }^{102}$ Utilitarian theories are more concerned with preventing recidivism and are more future oriented, while retributivist theories focus on the past and the punishment deserved by offenders. ${ }^{103}$ Factors such as time served in custody, gravity of the offence, criminal history of the offender, character of the offender and the offender's responsibility over third parties do not affect the sentence, specifically in the case where there are mandatory minimum sentences imposed by statute. ${ }^{104}$

Section 8 of the SOA, 2006 provides for mandatory prison terms for persons found guilty of the offence of defilement. ${ }^{105}$ The aim, it would seem, is to exert punishment on the accused, incapacitate them, and deter others from committing such an offence in future. ${ }^{106}$ Once the judicial officer hearing the case finds the accused person guilty of the offence, there is no discretion to consider the circumstances that led to the commission of the offence. The hands of the judicial officer are tied. ${ }^{107}$ This is despite the potential injustice that may arise

100 Jane Mumbi Gichubi v Republic,(2018) eKLR, para. 38.

101 Omus Kiringi Chivatsi v Republic (2017) eKLR, para. 4.

102 Hudson B, 'Understanding justice: An introduction to the ideas, perspectives and controversies in modern penal theory', 1996, 1, as cited in Gumboh E, 'A critical appraisal of the role of retribution in Malawian sentencing jurisprudence' Erasmus Law Review (2017) 1 - <http://www. erasmuslawreview.nl/tijdschrift/ELR/2017/3/ELR_2017_010_003_005 > on 10 November, 2018.

103 Gumboh E, 'A critical appraisal of the role of retribution in Malawian sentencing jurisprudence', 175.

104 See The judiciary of Kenya, Sentencing policy guidelines, 2016, 20.

105 See Section 8, The Sexual Offences Act, (Act. No. 3 of 2006).

106 See Kennedy Konde Munga v Republic, (2011) eKLR, 6.

107 See Kennedy Konde Munga v Republic, (2011) eKLR, 6. 
from the lack of mitigation. ${ }^{108}$ Perhaps as an unforeseen consequence, evidence of case law suggests that these mandatory minimum sentences have also ended up being mandatory maximum sentences. ${ }^{109}$

Some of the reasons advanced for the enactment of mandatory minimum sentences include deterrence, retribution and incapacitation of the offender; these being a firm response to serious crimes and promoting consistency in sentencing. ${ }^{110}$ This theory of punishment, however, ignores certain important considerations. For instance, retribution ignores some external factors that may arise in a defilement: poverty, disadvantage, discrimination, upbringing and harmful cultural practices. ${ }^{111}$ Similarly, the retributive model of mandatory imprisonment does not take into consideration the extent of moral blameworthiness of the offence. ${ }^{112}$ Moreover, Nielsen and Ehlers, commenting in the context of South Africa, state that it is difficult to find any evidence of reduction of the rate of crime since the introduction of mandatory minimum statutory sentences. ${ }^{113}$

Mandatory minimum sentences also have grave human rights implications. In the case of adolescents having consensual sex, the mandatory minimum sentences, in the author's view, go contrary to the import of Article 53 of the Constitution which provides that a child not be detained except as a measure of last resort. ${ }^{114}$ Mandatory minimum sentences also do not stand the principle of proportionality as one of the principles underpinning sentencing in Kenya. ${ }^{115}$ An excessive or harsh sentence would impinge on the accused person's right to have a fair determination of the matter. ${ }^{116}$

The Supreme Court of Canada, in the case of The Queen v Joseph Ryan Lloyd ${ }^{117}$ considered the mandatory minimum sentence in contradistinction to Section 12 of the Canadian Charter of Human Rights which prohibits cruel and

${ }^{108}$ See The judiciary of Kenya, Sentencing policy guidelines, 2016, 20.

109 Baehr K, 'Mandatory minimums making minimal difference: Ten years of sentencing sex offenders in South Africa' 20(1) Yale Journal of Law and Feminism, 2008, 228.

110 Macharia E, 'Sentencing in Botswana, a comparative analysis of law and practice', unpublished LLD Thesis, University of Pretoria, Pretoria, 2016, 251-252.

111 Gumboh E, 'A critical appraisal of the role of retribution in Malawian sentencing jurisprudence', 176.

112 Gumboh E, 'A critical appraisal of the role of retribution in Malawian sentencing jurisprudence', 183.

113 Nielsen J, and Ehlers L, 'Assessing the impact; mandatory and minimum sentences in South Africa' 14 South Africa Crime Quarterly, 2005, 15.

114 See Article 53 (f), Constitution of Kenya (2010).

115 The judiciary of Kenya, Sentencing policy guidelines, 2016, 12.

116 Article 50(1), Constitution of Kenya (2010).

117 The Queen v Joseph Ryan Lloyd (2016), Supreme court of Canada. 
unusual punishment in a case of drug trafficking. The court found that indeed the mandatory minimum sentence in that case contravened the Charter. The Court noted that 'mandatory minimum sentences that apply to offences that can be committed in various ways, under a broad array of circumstances and by a wide range of people are constitutionally vulnerable. ${ }^{118}$

This author argues for the inclusion of the utilitarian goals of rehabilitation of the offender into the sentencing of convicted persons under the SOA. Rehabilitation involves changing offenders' attitudes and mind-sets to reduce their likelihood of reoffending in the future. ${ }^{119}$ The main aim is to reform the person who has committed the crime, to avoid the said illegal behaviour. This can be done through rehabilitation and other alternative social mechanisms. ${ }^{120}$ In the author's view, the offence of defilement sometimes occurs within certain social contexts so that the court may be required to issue a rehabilitation order rather than imprison the accused. ${ }^{121}$ To this end, Oberman agrees that the sentencing of statutory rape should employ a more comprehensive range of punishment options. ${ }^{122}$

The Judiciary of Kenya has conceded that Kenyan jails are overcrowded owing to the overutilisation of custodial sentences by judicial officers. ${ }^{123}$ Perhaps it is time to reconsider the mandatory custodial sentences for persons found guilty of defilement depending on the circumstances of the case. In the case of adolescents having sexual intercourse with other adolescents, the aim of rehabilitating them rather than incarceration would be more appropriate. This could include guidance and counselling sessions, as well as probation. First-time offenders, for instance, who are not sex pests should be given another chance to make good their mistakes. For them to be punished by incarceration and their names entered into a sex offenders register, it could be argued, is too harsh and also disproportionate. ${ }^{124}$

${ }_{118}$ The Queen v Joseph Ryan Lloyd (2016), Supreme court of Canada, para. 133.

119 Bagaric M, Wolf $G$ and Rininger W, 'Mitigating America's mass incarceration crisis without compromising community protection: expanding the role of rehabilitation in sentencing' 22(1)

Lewis E Clark Law Review, 2018, 4.

120 Mishra S, 'Theories of punishment-a philosophical aspect'2(8) Imperial Journal of Interdisciplinary Research, 2016, 74.

121 See also State v Brian Masuku (2015), Zimbabwe High Court, para. 3.

122 Phipps C, 'Misdirected reform: On regulating consensual sexual activity between teenagers' 12(2) Cornell Journal of Law and Public Policy, 2003, 418.

123 The judiciary of Kenya, Sentencing Policy Guidelines, 2016, 5.

124 Oberman M, 'Regulating consensual sex with minors: Defining a role for statutory rape' Santa Clara Law Digital Commons, 2000, 776 -<https://digitalcommons.law.scu.edu/cgi/viewcontent. cgi?article $=1522 \&$ context... $>$ on 10 November 2018. 
The Supreme Court of Kenya also had opportunity to deal with the issue of mandatory sentences in the case of Francis Karioko Muruatetu $\& 2$ Others $v$ Republic. ${ }^{125}$ The case involved a challenge to the constitutionality of the mandatory death penalty for the offence of murder as provided for in the Kenyan Penal Code. ${ }^{126}$ The court noted that the right to a fair trial process does not end after conviction but proceeds up to the sentencing. ${ }^{127}$ Further, the court noted that the right to a fair trial is a non-derogable right under the CoK. ${ }^{128}$ Failure to allow an accused person to mitigate their sentence after conviction was found to deprive that person of the right to dignity. ${ }^{129}$ This is because there can be differing culpability of different murderers. ${ }^{130}$

\section{iv. The Potential Hindrance to the Realisation of the Right of Access to Reproductive Health}

Reproductive health implies that people are able to have a satisfying and safe sexual life and that they have the capability to reproduce and the freedom to decide if, when, and how often to do so. ${ }^{131}$ As a corollary to the right to reproductive health, both men and women have the right to be informed and to have access to safe, effective, affordable and acceptable methods of family planning of their choice which are not against the law, the right to relevant healthcare services which will enable women go safely through pregnancy and childbirth and provide couples with the best chance of having a healthy child. ${ }^{132}$ This is taking into account the right of the child to have parental care and protection, which includes equal responsibility of the mother and the father to provide for the child, even though they are not married. ${ }^{133}$

The criminalisation of sex with minors, especially adolescents, potentially hinders the realisation of the right of access to the highest standard of reproductive health of Kenyan adolescents. ${ }^{134}$ Article 43 of the CoK specifically

\footnotetext{
(2017) eKLR.

See Section 204, Penal Code (Cap 63 of the Laws of Kenya).

Francis Karioko Muruatetu \& Another v Republic (2017) eKLR, para. 41.

See Article 25, Constitution of Kenya (2010).

See Article 28, Constitution of Kenya (2010).

Francis Karioko Muruatetu E Another v Republic (2017) eKLR, para. 53.

31 Ayanleye A, 'Women and reproductive health rights in Nigeria' 6(5) OIDA International Journal of Sustainable Development, 2013, 128.

132 Ayanleye A O, 'Women and reproductive health rights in Nigeria', 128.

133 Article 53(1) (e), Constitution of Kenya (2010).

134 Ahmeda A, Kaplan M, Symington A, and Kismondi E, 'Criminalising consensual sexual behaviour in the context of HIV: Consequences, evidence, and leadership' 2011, Global Public Health, 6
} 
provides that each person has the right to the highest attainable standard of health, including reproductive health. ${ }^{135}$ The complete criminalisation of sex among persons below the age of eighteen, in the author's view, provides a chilling effect on any young person who wishes to seek sexual health care. Further, in the case of consensual relationships with an adult, the adolescents may shy away from accessing sexual and reproductive health services and counselling knowing that their partner might be arrested and prosecuted for the offence of defilement. ${ }^{136}$ It has also been argued that the indiscriminate criminalisation of consensual sexual relations also perpetuates stigma towards the affected adolescents' access to health care. ${ }^{137}$

According to Arshaougni, adolescents' lack of capacity to consent limits their access to healthcare. ${ }^{138}$ One such limitation is the highly punitive criminal laws put in place for sexual offences. There is, therefore, a need to find a better legal formulation for determining when adolescents can make informed independent healthcare decisions. ${ }^{139}$ To the extent that a sexually active adolescent must involve a third party before accessing these services may result in them shying away from seeking help. ${ }^{140}$ Delay or refusal to access these services acts to exacerbate the problem rather than to assist in curing the societal problem. ${ }^{141}$ Bhamjee and his collaborating authors when commenting on the Teddy Bear case found that, significantly, girls will be affected by criminal laws on defilement if their partner is older because their partner is committing an offence and they are required to give information which may potentially be used against the partner. ${ }^{142}$

-<https://www.tandfonline.com/doi/abs/10.1080/17441692.2011.623136?journalCode=rgph20 $>$ on 10 November 2018.

135 See Article 43(1) (a), Constitution of Kenya (2010).

136 English A, 'Statutory rape enforcement and child abuse reporting: Effects and health care access for adolescents' 50(3) DePaul Law Review, 2001, 843.

137 Kangaude G, 'Enhancing the role of health professionals in the advancement of adolescent sexual health and rights in Africa' 132 International Journal of Gynecology and Obstetrics, 2016, 106.

138 Arshaougni P, "But I am an adult now...sort of"; adolescent consent in health care decision making and the adolescent brain' 9 (2) Journal of Health Care Law and Policy, 2006, 316.

139 Arshaougni P, "But I am an adult now... sort of", 361.

140 See English A, 'Statutory rape enforcement and child abuse reporting: Effects and health care access for adolescents', 845.

141 See Teddy Bear Clinic for Abused Children and Another v Minister of Justice and Constitutional Development and Another, para. 72 - Khampepe J. notes that if the sexual behavior of adolescents is targeted by criminal law, the result is that adolescent sexual behaviour is driven underground and parents cannot therefore have a platform to encourage safe sexual practices.

142 Bhamjee S, Essack Z and Strode E, 'Amendments to the Sexual Offences Act dealing with consensual underage sex: Implications for doctors and researchers' 106(3) South African Medical Journal, 2016, 258. 
The Kenya Health Act provides that the National Health System shall devise and implement measures to promote health and to counter adverse health effects including implementation of means to unsafe sexual practices and also adolescence and youth sexual and reproductive health. ${ }^{143}$ The Kenya National Adolescent Sexual and Reproductive Health Policy of 2015 provides, as one of the strategies to reduce adolescents' vulnerability to HIV and AIDS and HPV, a policy to facilitate revision of age and sex-related restrictions that limit HIV, Sexual and Reproductive Rights. ${ }^{144}$ It would seem that the Government of Kenya has shown willingness to assist adolescents in their reproductive health issues. However, the continued criminalisation of consensual adolescent sex symbolically impacts the social lives of adolescents to the extent that forms of normal sexual expression are criminalised. ${ }^{145}$

\section{Comparative Jurisprudence}

South Africa has been progressive in reforming the law on defilement, especially regarding adolescents. To begin with, for sexual offences against children, the minimum age of consent is sixteen years. ${ }^{146}$ The country does not criminalise consensual teenage sexual intercourse. ${ }^{147}$ Further, Section 56 of the Sexual Offences Act of South Africa provides for a close-in-age exception for children accused of sexual assault. The age gap is capped at two years. ${ }^{148}$ The South African Constitutional Court takes the position that adolescents have some form of autonomy in making decisions such as whether to have sexual intercourse. ${ }^{149}$ Because adolescents above the age of sixteen have capacity to consent to sexual intercourse, there are significantly fewer barriers to access to reproductive health services. ${ }^{150}$

143 Section 68(1) (e)(i) and (ii), The Health Act, (Act No. 17 of 2017).

144 The ministry of health, Kenya, Kenya national adolescent sexual and reproductive health policy, $2015,18$.

145 See Teddy bear clinic for abused children and another $v$ Minister of justice and constitutional development and another, (2013) Constitutional Court of South Africa, para. 55.

146 Section 15, Criminal law (Sexual Offences and Related Matters) Amendment Act (No 32 of 2007).

${ }_{147}$ Teddy bear clinic for abused children and another $v$ Minister of justice and constitutional development and another (2013) Constitutional Court of South Africa, para. 55.

148 Section 56, The Sexual Offences Act (No 32 of 2007).

149 Teddy bear clinic for abused children and another $v$ Minister of justice and constitutional development and another (2013) Constitutional Court of South Africa, para. 52.

150 Strode A and Ezaack Z, 'Facilitating access to adolescent sexual and reproductive health services through legislative reform: Lessons from the South African experience' 107(9) South Africa Medical Journal, 2017,741. 
The Canadian Criminal Code perhaps provides for the best balance between the adolescent autonomy and protection from sexual exploitation. In Canada, the age of sexual consent with an adult was raised from fourteen years to sixteen in 2008 after a series of high profile cases involving luring of adolescents by the use of Internet. ${ }^{151}$ Adolescents above the age of sixteen are legally able to consent to sexual intercourse, except to anal intercourse, for which both parties must be eighteen years old and above. ${ }^{152}$ In the case of consensual sexual relations, children between the ages of fourteen and fifteen years old can consent to consensual sexual relations with persons who are less than five years older than they are. ${ }^{153}$ The said persons should also not be in a position of trust or authority or in a relationship of dependency towards the complainant. ${ }^{154}$

In the case of adolescents between the age of twelve and fourteen, they can consent to sexual intercourse but only with persons who are not more than two years older than them. ${ }^{155}$ Further, these persons should not have been in a position of trust, authority or in a position of dependency of the complainant. ${ }^{156}$ In effect, sexual assault against adolescents will be construed in accordance with the age difference between the parties. The Code does not afford a defence to the accused person who claims he thought the complainant was more than sixteen years old unless the accused provides evidence of the reasonable steps taken by him to confirm the age of the complainant. ${ }^{157}$ The onus shifts on the accused to prove their defence almost similar to the Kenyan Sexual Offences Act.

The Canadian Criminal Code makes further provision for the offence of sexual exploitation of a young person. ${ }^{158}$ Young persons are defined as persons who are over the age of sixteen but under the age of eighteen. ${ }^{159}$ This offence criminalises sexual touching with a young person by a person who is in a relationship of dependency, trust or authority with the young person. The court may make an inference of exploitation from the nature and circumstances of the case including the age of the young person, the age difference between the

151 Section 150.1 (1), The Canadian Criminal Code, also see, Benedet J, 'The age of innocence: A cautious defence of raising the age of consent in Canadian sexual assault law' 13 (4) Criminal Law Review, 2010, 1.

152 Section 159, The Canadian Criminal Code (RSC, 1985, c. C-46).

153 Section 150.1 (2.1), Canadian Criminal Code (RSC, 1985, c. C-46).

154 Section 150.1 (2.1) (b), Canadian Criminal Code (RSC, 1985, c. C-46).

155 Section 150.1(2), Canadian Criminal Code (RSC, 1985, c. C-46).

156 Section 151.1 (2), Canadian Criminal Code (RSC, 1985, c. C-46).

157 Section 151.1 (5), Canadian Criminal Code (RSC, 1985, c. C-46).

158 Section 153 (1), Canadian Criminal Code (RSC, 1985, c. C-46).

159 Section 153 (2), Canadian Criminal Code (RSC, 1985, c. C-46). 
person and the young person, the evolution of the relationship and the degree of control over the young person. ${ }^{160}$ The judicial officer is given wide guidelines in the Code to ensure there is no failure of justice.

\section{Proposals for Legislative Reform}

As we have already seen from the discussion above, the language of the SOA provides for stiff mandatory minimum sentences for persons found guilty of the offence of defilement. ${ }^{161}$ However, from the above discussion of the case of Francis Karioko Muruatetu v Republic, ${ }^{162}$ the Supreme Court of Kenya stated that the restriction of discretion in sentencing by judicial officers is contrary to the Bill of Rights. Further, some judges have rendered themselves in the press calling for an amendment of the Act to allow for judicial discretion. ${ }^{163}$ Judicial officers should therefore be given discretion in sentencing in cases of defilement to consider the circumstances that led to the said act. The mandatory sentences imposed by the SOA unduly restrict judicial officers to consider the unique circumstances of the case, where there is lower culpability. This will go a long way in safeguarding the rights of both parties and also in considering other objectives of sentencing such as reformation of the accused person and re-integration into the society.

The interpretation of Section 8(6) of the SOA that the accused must prove the steps taken to ascertain the age of the child, in the author's view, places an undue burden on accused persons. In the author's view, the accused person only ought to raise a reasonable defence, whereupon the court will decide whether the defence can stand or not. This is in line with the accused's right to silence as provided in the CoK. ${ }^{164}$

Finally, instead of the complete criminalisation of sexual intercourse with a person below the age of eighteen, the law can criminalise sexual intercourse with such persons based on the age gap between the victim and the perpetrator. It would seem rational to expect that an adult aged forty years can easily manipulate

\footnotetext{
Section 153 (2.1), Canadian Criminal Code (RSC, 1985, c. C-46).

See Section 8, Sexual Offences Act, (Act No. 3 of 2006).

Francis Karioko Muruatetu v Republic (2017) eKLR.

163 Ogemba P, 'Judges in Kenya root for review of Sexual offences act to end unfair penalties' The Standard, 3 October, 2016 - https://www.standardmedia.co.ke/article/2000218183/judges-inkenya-root-for-review-of-sexual-offences-act-to-end-unfair-penalties> on 10 November, 2018.

164 Article 50(i), Constitution of Kenya (2010).
} 
a minor aged sixteen years. The court would therefore be justified in punishing such an adult accordingly. ${ }^{165}$ Perhaps we could consider the 'close-in-age' exceptions, also known as 'Romeo and Juliet' clauses as in the Canadian Criminal Code. ${ }^{166}$ If the offenders are both minors and have, for example, a three year difference, criminal culpability should not attach. ${ }^{167}$

\section{Conclusion}

This study does not, in any way, condone or excuse sexual molestation and preying of children. It instead advocates for different approaches in combatting sexual offences other than or in addition to criminal sanctions. It finds that the Kenyan Sexual Offences Act of 2006 and its application fails to meet the ends of justice in the manner demonstrated above. It could be argued, for example, that where there is an unplanned pregnancy involved, the best interest of the unborn child would be that both the father and mother of the child be present in its life rather than one parent languishing in prison, depending on the context of the relationship between the two parents. Adults, too, must be warned of the effects of taking advantage of children sexually owing to the changes in societal norms. Finally, in the words of Skelton, if the state intends to delay the sexual debut of children, it should not do so by the use of criminal law but rather by a deliberate campaign of counselling, education and reproductive health services'. ${ }^{168}$

\footnotetext{
Kitrosser H, 'Meaningful consent: Toward a new generation of statutory rape laws', 331.

166 Drummond K, “'Cast me not away!” : The plight of modern day Romeo and Juliet'36(3) Quinnipiac Law Review, 2018, 462.

167 Kern L J, 'Trends in teen sex are changing, but are Minnesota's Romeo and Juliet Laws?' 39(5) William Mitchell Law Review, 2013, 1611.

168 Skelton A, 'Balancing autonomy and protection in children's rights: A South African account' 88 Temple Law Review, 2016, 90.
} 